\title{
Fin whales Balaenoptera physalus and minke whales Balaenoptera acutorostrata exploit a tidally driven island wake ecosystem in the Bay of Fundy
}

\author{
D. W. Johnston ${ }^{1,2, *}$, L. H. Thorne ${ }^{1,3}$, A. J. Read ${ }^{1}$ \\ ${ }^{1}$ Nicholas School of the Earth and Ocean Sciences, Duke University Marine Laboratory, 135 Duke Marine Lab Rd., \\ Beaufort, North Carolina 28516, USA \\ ${ }^{2}$ Joint Institute of Marine and Atmospheric Research, Pacific Islands Fisheries Science Center, 2750 Dole St. \\ Honolulu, Hawaii 96822, USA \\ ${ }^{3}$ Department of Zoology, University of Guelph, Guelph, Ontario N1H 2W1, Canada
}

\begin{abstract}
Marine predators forage in tidally induced oceanographic features, where they exploit predictable aggregations of prey. Very little, however, is known about how the physical forcing within these features affects their behaviour at a fine scale. During the summers of 2000 and 2002, we combined a series of cliff-top observations and boat-based surveys to describe the movements of fin whales Balaenoptera physalus and minke whales Balaenoptera acutorostrata within a predictable island wake occurring near Grand Manan Island in the Bay of Fundy, Canada. We recorded the location of fin and minke whales as they surfaced in or near the wake. We also examined the movements of individual fin whales using focal follow techniques to assess their habitat use within 3 distinct oceanographic regions (non-wake habitat, eddy habitat and free stream habitat) of the study area. Fin and minke whale occurrence was highest during flood tides and lowest during the mid-ebb phases. Fin (33) and minke whale (64) sightings were concentrated in areas characterised by slower current velocities - the region influenced by the eddy system formed within the wake. Nine individual fin whales, identified through photographs, spent a disproportionate amount of time within the eddy habitat portion of the study area, with occasional forays into free stream habitat. Foraging in the high-vorticity regions of the wake likely allows whales to exploit higher prey concentrations than in the free stream habitat or non-wake habitat.
\end{abstract}

KEY WORDS: Fin whale $\cdot$ Minke whale $\cdot$ Foraging $\cdot$ Island wake $\cdot$ Oceanography $\cdot$ Behaviour Resale or republication not permitted without written consent of the publisher

\section{INTRODUCTION}

The Bay of Fundy is known for its large tidal amplitudes (Trites \& Garrett 1983), which produce tidal currents exceeding $2 \mathrm{~m} \mathrm{~s}^{-1}$ in some coastal areas (Smith et al. 1984). In this region, many marine predators appear to forage in predictable, tidally driven oceanographic features (Gaskin 1983). For example, harbour porpoises Phocoena phocoena, fin whales Balaenoptera physalus, minke whales Balaenoptera acutorostrata and several species of seabirds congregate near the tip of Campobello Island to feed within localised upwellings and fronts (e.g. Gaskin \& Smith 1979, Braune
\& Gaskin 1982, Watts \& Gaskin 1985). Oceanographic surveys in this region linked the occurrence of several marine predators to upwellings and lower surface temperatures (Smith et al. 1984), but did not provide details on how these systems facilitated foraging.

Oceanographic features such as island wakes can be good foraging places for marine predators, as they are known to predictably aggregate plankton and weak nekton (Wolanski \& Hamner 1988). There are substantial gaps in our knowledge of the biophysical interface relative to upper trophic levels in these systems; most studies of marine predators in relation to oceanographic features make no attempt to link the physical 
forces in these regions with the foraging behaviours of the predators. There are several examples of birds and pelagic fish exploiting island and headland wakes (e.g. Uda \& Ishino 1958, Barkley 1972, Hunt \& Schneider 1987), and some studies examining odontocete and pinniped distributions within tidally induced oceanographic features (e.g. Acevedo 1991, Zamon 2001, Mendes et al. 2002, Johnston et al. 2005). However, little is known about the foraging patterns of other marine mammal species, and particularly of mysticetes, in such regions. Balaenopterid whales, such as fin and minke whales, are useful study subjects for assessing how large predators exploit on a fine scale. These large whales are relatively easy to follow (e.g. Richardson et al. 1995), often have predictable dive patterns while foraging (e.g. Croll et al. 2001) and, in many cases, can be individually identified by characteristic patterns in scars and pigmentation (Agler et al. 1993).

Grand Manan is a large island located near the mouth of the Bay of Fundy that obstructs tidal flow and produces an island wake off its northern tip during flood tides (Johnston et al. 2005). This oceanographic feature is locally referred to as the Long Eddy (Ward 1880). Both historical and recent studies suggest that marine predators aggregate within the Long Eddy to forage on prey aggregated within - or attracted to the wake. For example, Ward (1880) described how harbour porpoises frequented the area to feed on schools of Atlantic herring Clupea harengus harengus and mackerel Scomber scombrus. Read (1983) revealed that porpoise density was highest off the northern tip of Grand Manan during flood tides, and, most recently, satellite telemetry and line transect surveys revealed that some porpoises spend a large proportion of their time within the Long Eddy and confirmed that large numbers of porpoises forage in the Long Eddy during flood tides (Johnston et al. 2005).

The purpose of the present study was to assess the distribution of fin and minke whales within the Long Eddy island wake and to determine how these animals exploit the oceanographic feature in both time and space. To do this we employed cliff-top theodolite surveys to assess the distribution and occurrence of whales in the feature in relation to the structure of the inshore portion of the wake. We also conducted a series of boatbased observations of individually identifiable fin whales to assess the behavioural patterns of individual whales within definable habitat types within the wake.

\section{MATERIALS AND METHODS}

Study area and time frame. Our study area focused on an island wake system that occurs on flood tides off the northern tip of Grand Manan Island in the Bay of
Fundy (Fig. 1). Cliff-top observations of minke whales Balaenoptera acutorostrata and fin whales B. physalus were conducted in July and August 2000; boat-based observations of fin whales and oceanographic observations were conducted in July and August 2002. The study period was restricted to the summer months, as these are the months that exhibit the highest densities of both fin and minke whales, although some individuals of both species can be found locally throughout the year (Gaskin 1983).

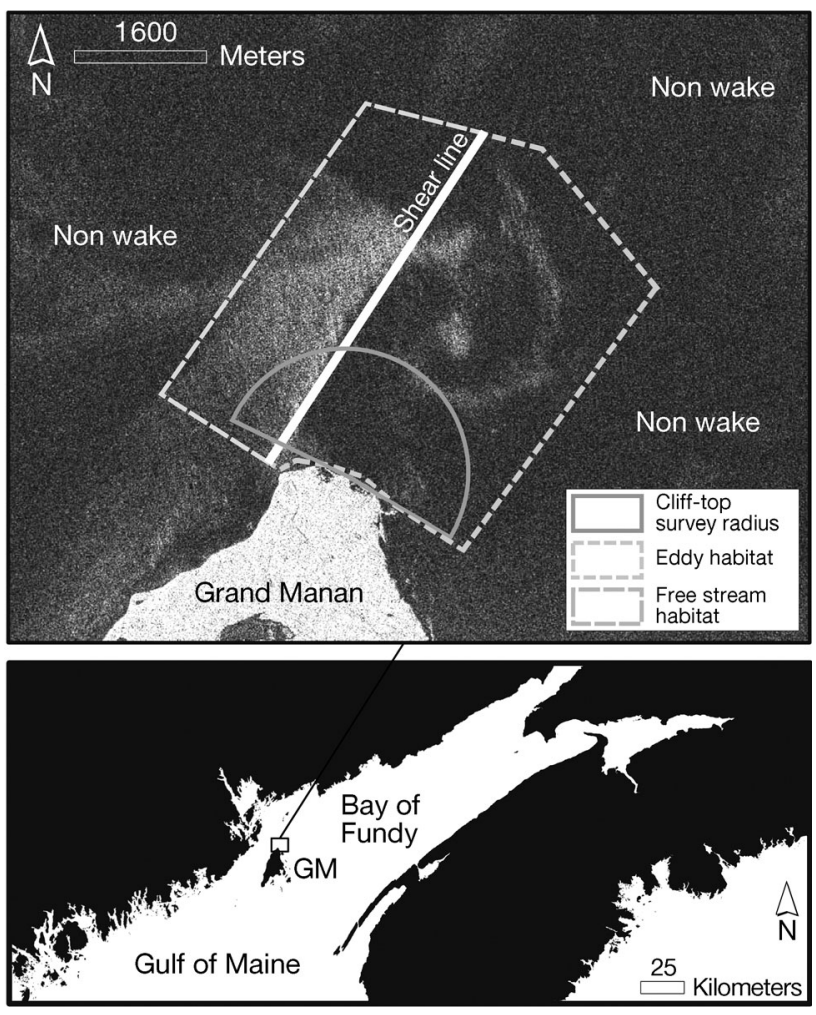

Fig. 1. Map of study area detailing locations of the Long Eddy, the $1500 \mathrm{~m}$ observation radius for cliff-top surveys and the 3 habitat regions of the island wake. Top panel illustrates the location of 3 habitat types and the cliff-top observation radius in relation to a RADARSAT synthetic aperture radar (SAR) image taken $2.25 \mathrm{~h}$ before high tide

Cliff-top surveys. The study area (Fig. 1) extended radially $1500 \mathrm{~m}$ offshore (the distance at which we could reliably differentiate between fin and minke whales) from a permanent observation point atop the 'Bishop', a prominent cliff at the northern tip of Grand Manan $\left(44^{\circ} 47^{\prime} 58^{\prime \prime} \mathrm{N}, 66^{\circ} 46^{\prime} 55^{\prime \prime} \mathrm{W}\right)$. This cliff represents a vantage point of between 33 and $35 \mathrm{~m}$ in height, depending on the tidal phase. We assessed the occurrence and spatial distribution of minke and fin whales in the vicinity of the Long Eddy through shorebased visual counts with $50 \times 8$ binoculars and sightings made with a digital theodolite (Geodimeter Sta- 
tion Model 600 digital theodolite; Spectra Precision Software). To examine tidal variation in habitat use of fin and minke whales at the Long Eddy, we conducted a $2 \mathrm{~h}$ observation period daily during the early, midand late flood tide from 12 July 2000 to 29 August 2000. Once each week we also conducted an observation period during the middle $90 \mathrm{~min}$ portion of the ebb tide. Each observation period was divided into $10 \mathrm{~min}$ segments to count and sight whales; each segment was separated by a 5 min interval to prevent observer fatigue. We recorded the locations of whales as described in Johnston (2002) and Ronconi \& St. Clair (2002). Briefly, we saved sightings of whales with Geodimeter Software Tools Version 2.01 (Spectra Precision Software), and used vertical and horizontal angles and station height to calculate the coordinates of points sighted offshore. To account for tidal fluctuations, the height of the observation point above sea level was calculated using tidal height corrected for North Head, Grand Manan Island. We then converted each sighting to northings and eastings relative to the theodolite station and mapped them using ArcGIS 8.3 (Environmental Systems Research Institute). Using these data, we produced a 'snapshot' of the study area for each sampling segment, detailing the location of whales sighted. For comparison with other studies of marine predators in the bay we randomised sampling periods throughout the flood-tide phase and reclassified survey data by time past low tide using the 90 min categories described by Braune \& Gaskin (1982).

Individual follows and photo-identification. We conducted photo-identification and focal follow surveys of individual fin whales on flood tides during July and August 2002. Surveys were conducted on clear days with a Beaufort sea-state $<2$ on a $6 \mathrm{~m}$ Fundy runabout ('Ahqik') with a $90 \mathrm{hp}, 4$ stroke engine. Following the conventions described in Mann (2000), we employed an individual follow approach and continuously sampled the focal animal for the duration of each follow. These methods are appropriate for fin whales, because they are readily identifiable and usually dive for periods of $<10$ min (Mann 2000). Furthermore, from previous theodolite surveys (above), we knew that fin whales occurred singly or in small groups in the study area, reducing the chance of confusing individuals.

We initiated each survey outside and south of the study area at a randomly chosen location. If a fin whale was not observed before reaching the Long Eddy, we then surveyed across the oceanographic feature in a randomised zigzag pattern until a fin whale was observed. During surveys, observers scanned the horizon in all directions for fin whale blows and kept track of the number of fin whales in the area. We followed fin whales at distances between 50 and $300 \mathrm{~m} ; 3$ trained observers recorded the distance and bearing to the locations of each surfacing, as well as the time of the sighting. Observers were trained to estimate distances to whales previous to the onset of the study by sighting proxies at various known distances. We followed fin whales for approximately $2 \mathrm{~h}$ or until they were lost. We continually recorded the position and heading of the boat with a Garmin 165 GPSMap global position system (GPS) with differential correction (average accuracy of $\pm 7 \mathrm{~m}$ ), and logged these data with a laptop computer running Logger 2000 (IFAW software). The distance and bearing of whale sightings were entered into the Logger database with the ShowData function at the end of each survey day. The software then correlated the positions of whales to GPS times and calculated the absolute locations of whale sightings. These positions were then exported as latitude and longitude geographic coordinates in decimal degrees for inclusion in a Geographic Information Systems (GIS) database.

During boat-based observations we photographed fin whales continuously with a Nikon F80 camera and a 100 to $300 \mathrm{~mm}$ Nikon lens. We used photographs taken with colour slide film (Fujifilm ASA 200 and 400) to identify whales, using scars, fin shapes, fin nicks and notches, and variation in pigmentation patterns. When possible, we obtained a series of pictures of both sides of a whale. Photographs were first taken of the right side of the animal to obtain pictures of the chevron and blaze patterns necessary for identification (Agler et al. 1993). We recorded the exposures taken of each whale, and exposures were stamped with the date and time by the camera. Two experienced judges assessed photographs of fin whales to identify individual whales, and choice of photographs and identification of whales followed methods detailed in Agler et al. (1990). Only those follows of a positively identified whale were used in further spatial analyses.

Spatial analysis - theodolite surveys. We mapped the positions of minke and fin whales obtained from the cliff-top surveys. For visual comparison purposes and to illustrate characteristic current velocities in the study area, we produced grids of flood-tide current velocities generated from Acoustic Doppler Current Profiler (ADCP) surveys conducted in August 2002 (Johnston 2004). These grids were produced from depth-averaged ( 7 to $52 \mathrm{~m}$ ) point values along a boxtype transect with ordinary kriging using the Geostatistical Analyst and the cell statistics function in the Spatial Analyst toolbox in ArcGIS 8.3.

Spatial analysis-boat-based observations. The sighting locations of individual fin whales were imported initially into ArcView 3.2 (Environmental Systems Research Institute), and we generated movement paths with the Animal Movement extension (Hooge \& Eichenlaub 1997). We then exported the movement paths from ArcView 3.2 and mapped them 
in ArcGIS 8.3 for further analysis. We subdivided the study area into 3 discrete habitat types, based on oceanographic analyses and remote sensing surveys (Johnston 2004, Johnston et al. 2005). These habitat types were: non-wake, eddy and free stream (Fig. 1). Non-wake habitat was comprised of the area unaffected by the island wake itself, and surrounded both eddy and free stream habitat. Eddy habitat was comprised of the area on the leeward side of the shear line in the wake affected by the anti-cyclonic eddy. Oceanographic surveys revealed that this portion of the island wake generally exhibits relatively slow current velocities (Johnston 2004). Free stream habitat was comprised of the region northwest of the shear line, and its outer boundary was delineated by the extent of the oceanographic feature visible on RADARSAT synthetic aperture radar images (e.g. Fig. 1). Free stream habitat exhibited relatively high current velocities (Johnston 2004). The shear line corresponds to an average of the location of the velocity front within the island wake during flood tides as observed by LANDSAT and RADARSAT images at various stages of the flood tide and by ADCP surveys.

We then conducted a habitat use versus availability analysis, as previously described in Gannon (2003), Allen et al. (2001) and Alldredge \& Ratti (1986). Our approach was to assess habitat use by individual fin whales, by examining both habitat use and habitat availability for each individual (Garshelis 2000). We calculated the proportions of non-wake habitat, eddy habitat and free stream habitat available to each whale during the individual focal follow. The extent of non-wake habitat available to each whale was determined by calculating the area within which that fin whale could have travelled during the follow at an estimated maximum sustained cruising speed of $14.8 \mathrm{~km} \mathrm{~h}^{-1}$ (Aguilar 2002) and by subtracting the area of land and wake habitats from this. We used a Friedman's test (Zar 1999) to compare the proportion of each habitat available with the proportion of time during each track spent within each available habitat. We then employed a post hoc Tukey's Honestly Significant Difference (HSD) test (Zar 1999) to assess specific differences of habitat use by individual fin whales amongst the available habitat types. In order to avoid pseudo-replication, we pooled the time-habitat proportions of individual whales followed multiple times (Garshelis 2000), resulting in 5 comparisons of habitat use versus availability.

\section{RESULTS}

Our cliff-top surveys revealed that both fin whale Balaenoptera physalus and minke whale B. acutorostrata occurrence (percentage of survey periods with $\geq 1$ whales present) was greatest in the flood-tide phase and that the study area was generally not used during the mid-ebb portion of the tidal phase (Fig. 2). The occurrence of fin whales peaked at mid-flood, and few whales used the inshore portion of the Long Eddy at slack high water. Minke whale occurrence was also high at mid-flood, but highest at slack high water (Fig. 2). The positions of all whales sighted on flood tides and the mean depth-averaged current velocity grid for flood tides are presented in Fig. 3. Both minke and fin whales tended to surface in the eastern lee of the island, in an area that exhibits lower current velocities (Fig. 3).

Fin whales were sighted on 15 survey days, and quality photographs of whales were obtained on 14 of these days. On most days, there were 1 or 2 fin whales present in the Long Eddy, together with 3 to 7 minke whales and numerous harbour porpoises (Johnston et al. 2005). On 2 survey days, 3 fin whales foraged within the Long Eddy, and no focal follows were conducted. Through the examination of photographs, we identified 9 fin whales based on scars, fin notches and nicks, and pigmentation patterns. Whales were given names to avoid confusion during analysis. Two whales ('Thelonious' and 'Rheinhardt') were photographed 3 times during the study period, 1 whale ('Getz') was

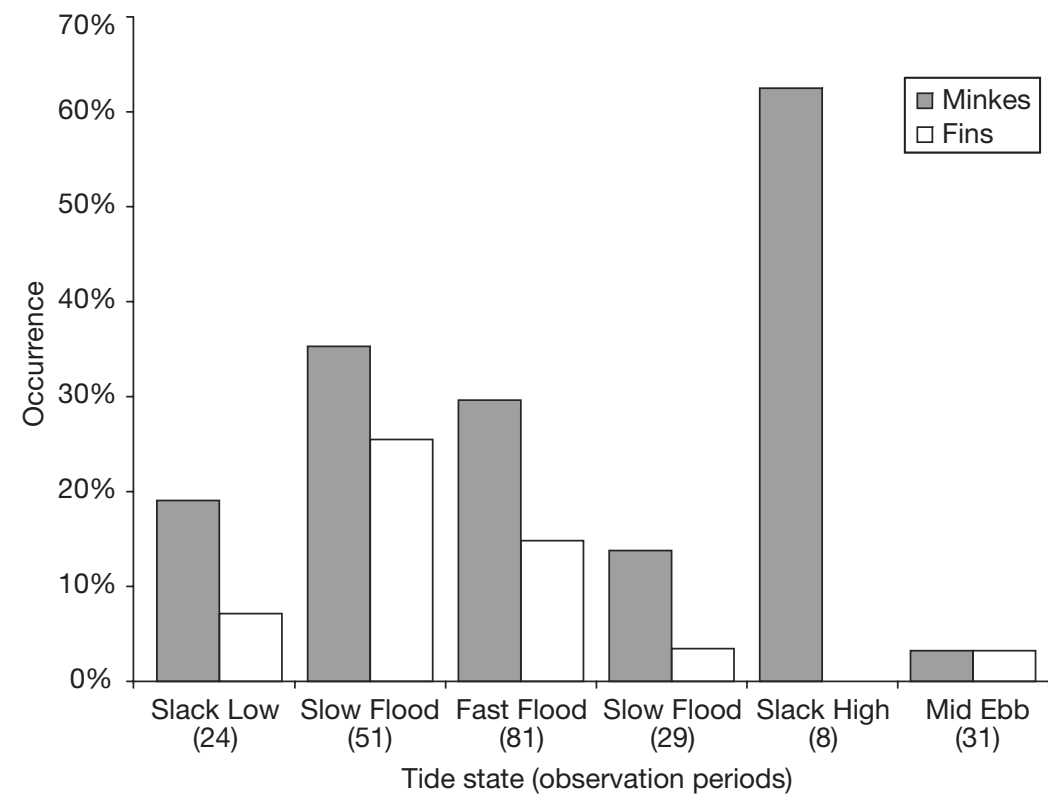

Fig. 2. Balaenoptera physalus and B. acutorostrata. Occurrence of fin and minke whales from visual scans of the Long Eddy during 5 flood-tide phases and 1 ebb-tide phase 


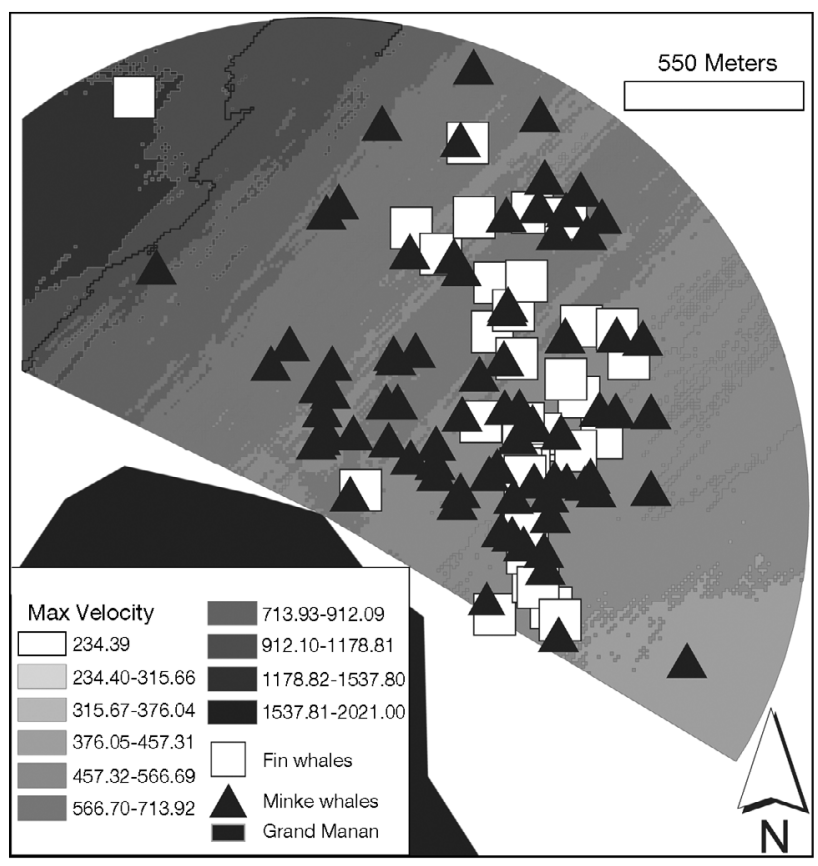

Fig. 3. Balaenoptera physalus and B. acutorostrata. Locations of fin and minke whales sighted by digital theodolite during flood tide in the Long Eddy. Sightings are superimposed over depth-averaged grids of mean flood-tide current velocities derived from ADCP surveys. Current velocities are in $\mathrm{mm} \mathrm{s}^{-1}$

photographed 4 times and another whale ('Otis') was photographed 5 times in the Long Eddy during the study period. Five whales ('Redman', 'Sonny', 'Mingus', 'Oscar' and 'Sco') were only photographed once in the Long Eddy. With the exception of Otis, whales that revisited the Long Eddy did so within a period of 8 to $11 \mathrm{~d}$. Otis was initially identified on $18 \mathrm{July}$, and revisited the Long Eddy 4 times within a period of $8 \mathrm{~d}$ beginning on 16 August.

We conducted 10 focal follows of fin whales during our $12 \mathrm{~d}$ survey. Details of their movements are presented in Table 1, and a track representing the movement of 1 individual fin whale through the study area, including details on the 3 wake habitat types used in the habitat availability versus use analysis, is presented in Fig. 4. Several whales were followed repeatedly on different days. Both Thelonius and Otis were followed 3 times; Getz was followed twice. Both Redman and Rheinhardt were followed once. All but 1 of the followed whales focused their movements within the island wake. The notable exception being Thelonius on 27 July 2002, when the whale left the study site and travelled SE to Swallowtail, Grand Manan. The proportion of available non-wake habitat was large for all whales, but they spent only a small proportion of time within this habitat type (Table 1). Both eddy and free stream habitat represented only small proportions of the available habitat, but whales spent the largest proportion of their time within the eddy habitat (Table 1). The result of the Friedman habitat use and availability analysis was significant $(p=0.007)$. Non-wake habitat was ranked lowest, and, within the wake system, the eddy habitat was ranked highest. The post hoc tests indicated that these differences in habitat use were statistically significant $(p=0.043)$.

\section{DISCUSSION}

Our cliff-top surveys revealed that both minke whales Balaenoptera acutorostrata and fin whales $B$. physalus used the study area more frequently during flood tides than during ebb tides; this finding is consistent with other studies of marine predators at this location (e.g. Read 1983, Dayer 2001). Interestingly, minke whale occurrence was highest during the slack high-tide phase, although the number of observational periods for this portion of the tidal phase was lowest (8).

Island and headland wakes are often extremely dynamic systems (Wolanski et al. 1984, Geyer 1993, Furukawa \& Wolanski 1998, Johnston et al. 2005), but maintain some level of spatial and temporal coherence. This may be especially true of tidally induced systems, which are generated by a predictable tidal regime. Island and headland wake systems are often comprised of 2 regions or water masses exhibiting extremely different current velocities and patterns. These regions are delineated by a flow-separation or shear line (Hamner \& Hauri 1981, Geyer 1993, Wolanski et al. 1996). The shear line represents a front between rapidly flowing water (that has separated from the edge of the island or headland) and more slowly moving water in the lee of the island or headland (Geyer 1993, Wolanski et al. 1996). In this leeward region, 1 or more eddies usually form (Alldredge \& Hamner 1980, Signell \& Geyer 1991), and secondary circulation

Table 1. Balaenoptera physalus. Proportions (\% total) of 3 habitat types and of track time spent in those habitat types for 5 individually identified fin whales foraging in the Long Eddy, Bay of Fundy, Canada

\begin{tabular}{|lcccccc|}
\hline \multirow{2}{*}{ Whales } & \multicolumn{3}{c}{ Habitat available } & \multicolumn{3}{c|}{ Time within available habitat } \\
\cline { 2 - 4 } & Non-wake & Eddy & Free stream & Non-wake & Eddy & Free stream \\
\hline Thelonius & 99.21 & 0.29 & 0.51 & 62.86 & 37.14 & 0.00 \\
Otis & 99.41 & 0.22 & 0.38 & 0.00 & 93.10 & 6.90 \\
Getz & 98.43 & 0.57 & 1.00 & 0.00 & 97.15 & 2.85 \\
Redman & 98.44 & 0.57 & 0.99 & 1.00 & 99.00 & 0.00 \\
Rheinhardt & 98.99 & 0.37 & 0.64 & 0.00 & 99.03 & 0.97 \\
\hline
\end{tabular}




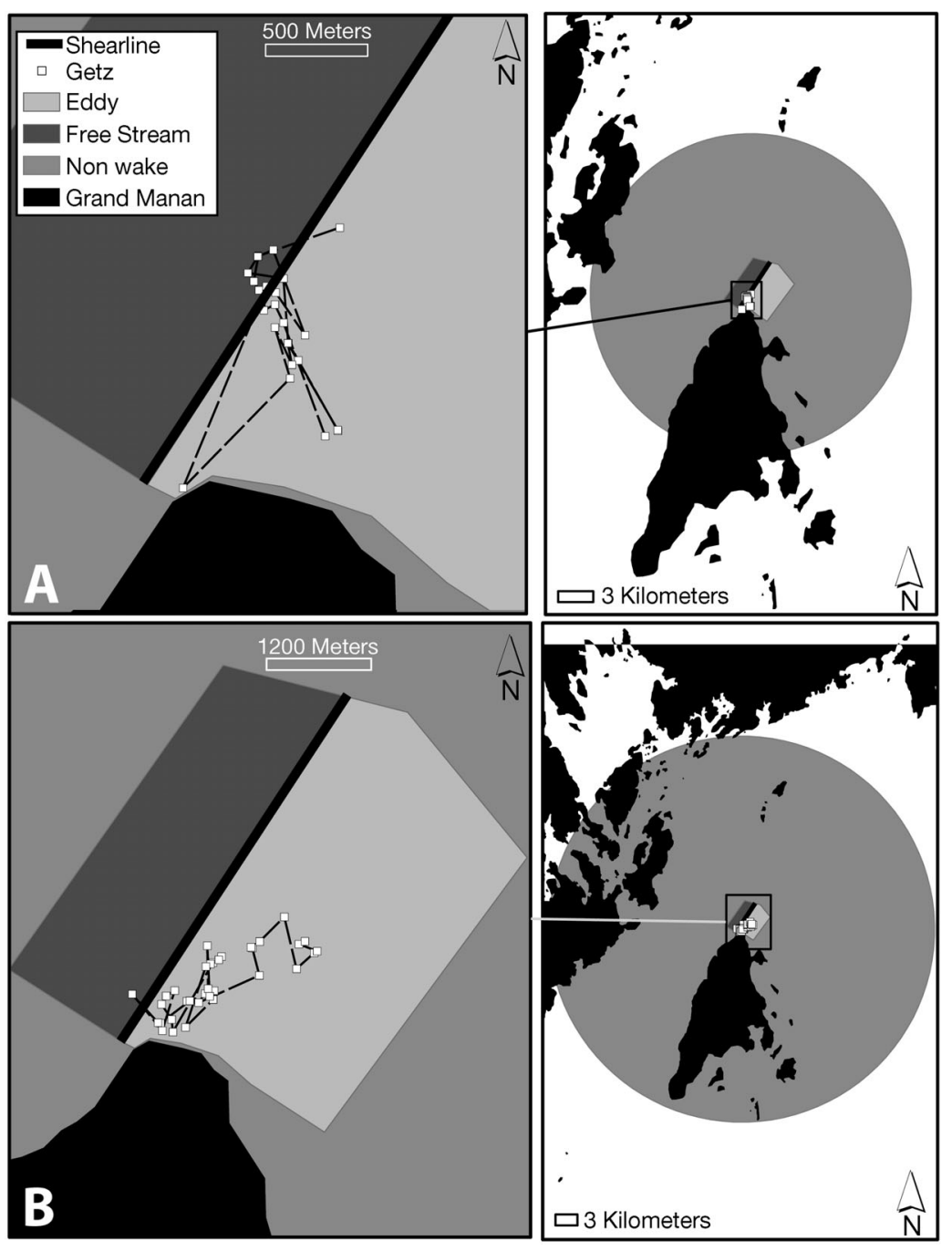

Fig. 4. Balaenoptera physalus. Path of the fin whale named Getz in non-wake, eddy and free stream habitats during $2 \mathrm{~h}$ flood-tide follows on (A) 17 August 2002 and (B) 7 August 2002

within these eddies controls the aggregation of plankton and weak nekton into predictable locations (Wolanski \& Hamner 1988, Wolanski et al. 1996).

The positions of both minke and fin whale surfacings were clearly located in areas of the wake that are known to exhibit slower current velocities. Our ADCP surveys were not synoptic with the cliff-top observations of animals. However, both other oceanographic and remote sensing surveys of the wake (collected on multiple days over a $2 \mathrm{yr}$ period) have revealed considerable predictability in this region (Johnston 2004), and the current data derived from these oceanographic surveys are consistent with observations of current patterns in other island and headland wakes. Considering this predictability, we assume that the relationship between regions of high-velocity currents and low-velocity currents remains relatively stable in the inshore region. In addition, the positions of whales were recorded over a $6 \mathrm{wk}$ period, sampling whales throughout at least 1 complete cycle between spring and neap tides. Further research is required to understand how variation in tidal amplitude associated with the lunar cycle might affect the function of the Long Eddy island wake.

The follows of individual fin whales revealed that large portions of habitat were available to them (often encompassing several other areas known to be fin and minke whale foraging sites, such as Briar Island to the east, Head Harbour Passage to the northeast and Old Proprietor shoals to the southeast, Gaskin 1983), but they focused their movements within the Long Eddy island wake and, in general, within the eddy portion of the wake. Island wakes are known to concentrate prey due to the evolution of secondary flows (Wolanski et al. 1996), and the Long Eddy appears to work in a similar way. Oceanographic surveys and hydro-acoustic and mid-water trawl prey surveys indicate that the Long Eddy accumulates herring Clupea harengus and large zooplankton, such as euphausiids, in predictable near-surface regions along the shear line and edges of the eddy (Johnston et al. 2005). We assume that both fin and minke whales exploit these prey aggregations within the eddy portion of the wake and, perhaps, make forays into the shear line to exploit aggregations there.

Foraging in the low-velocity eddy region may represent an optimal strategy for whales exploiting island wakes. Encounter rates with prey are likely to be higher than in surrounding waters, due to prey aggregation within the eddy and to slower current speeds, which could reduce the effort required by whales to maintain their position. There are examples at various scales in other systems to support this hypothesis. For example, rocks in streams also produce wakes that appear to function similarly to the Long Eddy. Some studies have illustrated that velocity gradients produced by these obstructions in streams are exploited by feeding brown trout Salmo trutta and brook trout Salvelinus fontinalis (Hayes 1991, Hayes \& Jowett 1994). It is also apparent that flow velocity greatly influences the distribution of invertebrates in rivers and streams (Swan \& Palmer 2000).

The lack of obvious directionality of individual fin whale movements resembles descriptions of the foraging 
behaviour of other marine predators at a number of spatial and temporal scales (Stevick et al. 2002). This type of movement, often referred to as an area-restricted search pattern (e.g. Kareiva \& Odell 1987), results from decisions made by the individuals to remain proximate to high-density patches of prey (Stevick et al. 2002). These decisions are reflected by higher turn rates and slower travel rates (Fauchald \& Tveraa 2003). In the present study, it appears likely that individual whales experienced high-density prey patches in the eddy portion of habitat within the island wake.

Free stream habitat was ranked lower in terms of habitat use by individual whales than the eddy region. Free stream habitat within island wakes generally exhibits elevated current velocities, and moving through high current velocities would likely require greater effort by fin whales to orient and maintain their position. Higher current speeds may also translate into more transitory and less coherent patches of euphausiids and small pelagic fishes such as juvenile herring, as rapidly moving water $\left(2.0+\mathrm{m} \mathrm{s}^{-1}\right)$ would sweep them rapidly along and possibly disrupt them. The fact that whales generally chose free stream habitat over non-wake habitat may stem simply from proximity, or may represent occasional but intentional forays into and across the shear line in search of prey. Such exploratory movements away from high-density prey areas are common features of many foraging strategies (Stevick et al. 2002).

The shear line itself may play a functional role in how marine predators exploit island wakes. Many marine mammals exploit barriers when feeding, to limit the number of possible escape routes for their prey. The shear lines between different velocity regions, and the accumulation of air bubbles, plankton and nekton within them (e.g. Farmer et al. 1995), may be detectable and actively avoided by prey species such as herring, representing a functional barrier for marine mammals in the Long Eddy to feed against. Prey herded towards and through a shear line may also move in a predictable fashion when encountering the different current regime. Herring exhibit positive rheotaxis (Jovallanos \& Gaskin 1983), and such predictable movements in prey schools may be anticipated by whales that forage frequently in these systems, facilitating prey capture attempts. Further research is required to determine if whales exploit island and headland wakes in this manner.

Some fin whales repeatedly exploited the Long Eddy as a foraging site during the summer of 2002. We cannot infer any level of site fidelity from our data, as we know little about the movement and habitats used by whales when not foraging within the Long Eddy. Interestingly, during the summer of 2002, we identified 1 fin whale foraging during the ebb tide near Old Proprietor
Shoal, southeast of Grand Manan, and the same whale was observed foraging within the Long Eddy on the following flood tide later that day. These results are consistent with other observations of fin whales foraging at Old Proprietor Shoal during ebb tides (Gaskin 1983) and the hypothesis that fin whales choose foraging sites based on tidal phase and related oceanographic phenomena (Gaskin \& Smith 1979).

The Long Eddy supports a predictable multi-species feeding aggregation of marine organisms, including numerous large predators that forage on both fishes and plankton. This suggests that the oceanographic feature aggregates prey in relatively large quantities and makes it available to predators employing different foraging strategies. During our boatbased and shore-based surveys we witnessed only 1 example of surface feeding, when a minke whale lunged at the surface. It is possible that both minke and fin whales are lunge feeding below the surface, as fin and blue whales do in the waters of California (Acevedo-Gutierrez et al. 2002). Unfortunately, it is very difficult to measure the prey field within the Long Eddy. The rapid current velocities and dynamic patterns of water flow limit the utility of traditional sampling gear, such as plankton nets and mid-water trawls. Nevertheless, qualitative hydro-acoustic and trawl surveys revealed that the Long Eddy aggregates biomass into predictable areas and that these aggregations include herring and euphausiids (Johnston et al. 2005), the primary prey of both fin whales and minke whales. Although we have no quantitative measures of prey availability, we predict that dense concentrations of prey are available to fin whales feeding within this area (cf. Brodie et al. 1978), as the Long Eddy predictably attracts multiple fin whales at least twice per day. Similarly, there must be copious quantities of herring available to support several minke whales, hundreds of harbour porpoises, and perhaps thousands of piscivorous sea birds at each flood tide (Johnston et al. 2005). Further research is required to assess quantitatively the prey field within the Long Eddy.

Our observations suggest that the Long Eddy is a predictable foraging site for minke and fin whales and that they focus their movements within slower velocity regions of the wake to exploit prey aggregations occurring there. The Long Eddy may be an important feeding site for a variety of marine predators within the bay, although its true importance requires a better understanding of the proportion of each population that uses the Long Eddy as a foraging site. However, particularly in years of reduced prey abundance, these types of oceanographic features that aggregate prey may be extremely important to marine predators in the Bay of Fundy. 
Acknowledgements. This work was supported by research grants and in-kind support from the Disney Conservation Foundation, the International Fund for Animal Welfare and Radarsat International's Data for Research Use Program. We thank the staff of the Grand Manan Whale and Seabird Research station for field and logistical support. Special thanks to Dick Barber, Larry Crowder, Rob McLaughlin, Doug Nowacek and Tom Nudds for their help with analysis, design and manuscript review, and to Kim Urian, Danielle Waples, Kerry Irish, Ashley Dayer and Katie Kuker for assistance with photo-ID techniques and visual surveys. Portions of this manuscript were improved by comments from Damon Gannon. This research was conducted under permits from the Canadian Department of Fisheries and Oceans and with approval from the Duke University Institutional Animal Care \& Use Committee (IACUC).

\section{LITERATURE CITED}

Acevedo A (1991) Behaviour and movements of bottlenose dolphins, Tursiops truncatus, in the entrance to Ensenada de La Paz, Mexico. Aquat Mamm 17:137-147

Acevedo-Gutierrez A, Croll DA, Tershy BR (2002) High feeding costs limit dive time in the largest whales. J Exp Biol 205:1747-1753

Agler BA, Schooley RL, Frohock SE, Katona SK, Seipt IE (1993) Reproduction of photographically identified fin whales, Balaenoptera physalus, from the Gulf of Maine. J Mamm 74:577-587

Aguilar A (2002) Fin whale, Balaenoptera physalus. In: Perrin WF, Wursig B, Thewissen JGM (eds) Encyclopedia of marine mammals. Academic Press, San Diego CA, p 435-438

Alldredge AL, Hamner WM (1980) Recurring aggregation of zooplankton by a tidal current. Estuar Coast Mar Sci 10: 31-37

Alldredge JR, Ratti JT (1986) Comparison of some statistical techniques for analysis of resource selection. J Wildl Manag 50:157-165

Allen MC, Read AJ, Gaudet J, Sayigh LS (2001) Fine-scale habitat selection of foraging bottlenose dolphins Tursiops truncatus near Clearwater, Florida. Mar Ecol Prog Ser 222: 253-264

Barkley RA (1972) Johnston Atoll's wake. J Mar Res 30: 201-216

Braune BM, Gaskin DE (1982) Feeding ecology of nonbreeding populations of larids off Deer-Island New-Brunswick Canada. Auk 99:67-76

Brodie PF, Sameoto DD, Sheldon RW (1978) Population densities of euphausiids off Nova-Scotia as indicated by net sample whale stomach contents and sonar. Limnol Oceanogr 23:1264-1267

Croll DA, Acevedo-Gutierrez A, Tershy BR, Urban-Ramirez J (2001) The diving behavior of blue and fin whales: Is dive duration shorter than expected based on oxygen stores? Comp Biochem Physiol A 129:797-809

Dayer A (2001) Temporal and spatial regularity of seabird and marine mammal foraging in a tidally-driven local upwelling off Grand Manan Island, Bay of Fundy. BSc Honours thesis, Harvard University, Cambridge, MA

Farmer DM, D'Asaro EA, Trevorrow MV, Dairiki GT (1995) Three-dimensional structure in a tidal convergence front. Contin Shelf Res 15:1649-1673

Fauchald P, Tveraa T (2003) Using first-passage time in the analysis of area-restricted search and habitat selection. Ecology 84:282-288
Furukawa K, Wolanski E (1998) Shallow-water frictional effects in island wakes. Estuar Coast Shelf Sci 46:599-608

Gannon DP (2003) Behavioral ecology of an acoustically mediated predator-prey system: bottlenose dolphins and sciaenid fishes. Ph D thesis, Duke University, Durham, NC

Garshelis DL (2000) Delusions in habitat evaluation: measuring use, selection and importance. In: Boitani L, Fuller TK (eds) Research techniques in animal ecology controversies and consequences. Columbia University Press, New York, p 111-164

Gaskin DE (1983) The marine mammal community. In: Thomas MLH (ed) Marine and coastal systems of the Quoddy region, New Brunswick. Can Spec Publ Fish Aquat Sci 64:245-268

Gaskin DE, Smith GJD (1979) Observations on marine mammals, birds and environmental conditions in the Head Harbour region of the Bay of Fundy. In: Scarratt DJ (ed) Evaluation of recent data relative to potential oil spills in the Passamaquoddy area. Fish Mar Serv Tech Rep 901:69-86

Geyer WR (1993) Three dimensional tidal flow around headlands. J Geophys Res 98:955-966

Hamner WM, Hauri IR (1981) Effects of island mass water flow and plankton pattern around a reef in the Great Barrier Reef lagoon Australia. Limnol Oceanogr 26: 1084-1102

Hayes J (1991) Microhabitat used by large brown trout for drift feeding. Freshw Catch 45:7-9

Hayes JW, Jowett IG (1994) Microhabitat models of large drift-feeding brown trout inthree New Zealand rivers. N Am J Fish Manag 14:710-725

Hooge PN, Eichenlaub B (1997) Animal movement extension to Arcview. Alaska Science Center, Biological Science Office, U.S. Geological Survey, Anchorage, AK

Hunt GL, Schneider DC (1987) Scale-dependent processes in the marine environment. In: Croxall JP (ed) Seabirds feeding ecology and role in marine ecosystems. Cambridge University Press, Cambridge, p 7-43

Johnston DW (2002) The effect of acoustic harassment devices on harbour porpoises (Phocoena phocoena) in the Bay of Fundy, Canada. Biol Conserv 108:113-118

Johnston DW (2004) Fine scale oceanographic features and foraging marine predators: the ecology and conservation of an island wake in the Bay of Fundy, Canada. PhD thesis, Duke University, Durham, NC

Johnston DW, Westgate AJ, Read AJ (2005) Effects of fine scale oceanographic features on the distribution and movements of harbour porpoises Phocoena phocoena in the Bay of Fundy. Mar Ecol Prog Ser 295:279-293

Jovallanos CL, Gaskin DE (1983) Predicting the movements of juvenile Atlantic herring (Clupea harengus herengus) in the SW Bay of Fundy using computer simulation techniques. Can J Fish Aquat Sci 40:139-146

Kareiva PM, Odell G (1987) Swarms of predators exhibit 'preytaxis' if individual predators use area-restricted search. Am Nat 130:223-270

Mann J (2000) Unraveling the dynamics of social life. Long term studies and observational methods. In: Mann J, Connor RC, Tyack PL, Whitehead H (eds) Cetacean societies: field studies of dolphins and whales. University of Chicago Press, Chicago, IL, p 45-64

Mendes S, Turrell W, Luetkebohle T, Thompson P (2002) Influence of the tidal cycle and a tidal intrusion front on the spatio-temporal distribution of coastal bottlenose dolphins. Mar Ecol Prog Ser 239:221-229

Read AJ (1983) Movements and distribution of harbour porpoises Phocoena phocoena (L.), in the western Bay of 
Fundy. MSc thesis, University of Guelph

Richardson WJ, Finley KJ, Miller GW, Davis RA, Koski WR (1995) Feeding, social and migration behavior of bowhead whales, Balaena mysticetus, in Baffin Bay vs. the Beaufort Sea - regions with different amounts of human activity. Mar Mammal Sci 11:1-45

Ronconi RA, St. Clair CC (2002) Management options to reduce boat disturbance on foraging black guillemots (Cepphus grylle) in the Bay of Fundy. Biol Conserv 108: 265-271

Signell RP, Geyer WR (1991) Transient eddy formation around headlands. J Geophys Res 96:2561-2575

Smith GJD, Jovallanos CL, Gaskin DE (1984) Near-surface bio-oceanographic phenomena in the Quoddy region, Bay of Fundy. Can Tech Rep Fish Aquat Sci 1280:124

Stevick PT, McConnell BJ, Hammond PS (2002) Patterns of movement. In: Hoelzel AR (ed) Marine mammal biology: an evolutionary approach. Blackwell Science, Oxford, p 185-216

Swan CM, Palmer MA (2000) What drives small-scale spatial patterns in lotic meiofauna communities? Freshw Biol 44: 109-122

Trites RW, Garrett CJR (1983) Physical oceanography of the Quoddy region. In: Thomas MLH (ed) Marine and coastal

Editorial responsibility: Otto Kinne (Editor-in-Chief), Oldendorf/Luhe, Germany systems of the Quoddy region, New Brunswick. Can Spec Publ Fish Aquat Sci 64:9-34

Uda M, Ishino M (1958) Enrichment patterns resulting from eddy systems in relation to fishing grounds. J Tokyo Univ Fish 44:105-129

Ward CC (1880) Porpoise-shooting. Scribners Mon 20: $801-812$

Watts P, Gaskin DE (1985) Habitat index analysis of the harbor porpoise Phocoena phocoena in the southern coastal Bay of Fundy, Canada. J Mamm 66:733-744

Wolanski E, Hamner WM (1988) Topographically controlled fronts in the ocean and their biological influence. Science 241:177-181

Wolanski E, Imberger J, Heron ML (1984) Island wakes in shallow coastal waters. J Geophys Res 89:10 553-10 569

Wolanski E, Asaeda T, Tanaka A, Deleersnijder E (1996) Three-dimensional island wakes in the field, laboratory experiments and numerical models. Contin Shelf Res 16: $1437-1452$

Zamon JE (2001) Seal predation on salmon and forage fish schools as a function of tidal currents in the San Juan Islands, Washington, USA. Fish Oceanogr 10:353-366

Zar JH (1999) Biostatistical analysis. Prentice Hall, Upper Saddle River, NJ

Submitted: May 13, 2004; Accepted: July 15, 2005

Proofs received from author(s): November 11, 2005 